\title{
Nematocysts of Chiropsalmus quadrumanus with comments on the systematic status of the Cubomedusae
}

\author{
D. R. Calder \& E. C. Péters \\ Marine Resources Research Institute; \\ Charleston, South Carolina, USA
}

\begin{abstract}
KURZFASSUNG: Nematocysten von Cbiropsalmus quadrumanus mit Anmerkungen zum systematischen Status der Cubomedusen. Der Bau der Nesselkapseln der Würfelqualle Chiropsalmus quadrumanus wurde an Exemplaren aus dem Küstenbereich von South Carolina und von Georgia (USA) lichtmikroskopisch untersucht. Das Cnidom besteht aus Isorhizen, mikrobasischen Mastigophoren und heterotrichen mikrobasischen Eurytelen. Mastigophoren sind lediglich bei Hydrozoen und Anthozoen sowie unter den Scyphozoen nur bei Cubomedusen gefunden worden. In Ubereinstimmung mit neueren Ergebnissen über den Lebenszyklus dieser Formen weist dieser Befund darauf hin, daß sich die Cubomedusen von anderen Scyphozoen deutlich unterscheiden und als eigene Unterklasse oder Klasse einzuordnen sind.
\end{abstract}

\section{INTRODUCTION}

Among the most venomous animals in the sea are the Cubomedusae or "sea wasps", a group of jellyfishes typically inhabiting neritic waters of the tropics and subtropics. Most known species of Cubomedusae are capable of inflicting at least a mild sting, and several are highly toxic. A number of human fatalities along the coasts of Australia, Indonesia, Malaysia, and the Philippines have been attributed to sea wasp stings (Kingston \& Southcott, 1960; Cleland \& Southcott, 1965; Halstead, 1965; BARNES, 1966).

Cubomedusae have generally been regarded as scyphozoans, although they differ significantly in morphology from other representatives of the class. For example, the medusa stage has a velarium, analogous to the velum of hydrozoan medusae, at the margin of the clear, cuboidal bell. Nematocysts on the tentacles occur in rings, and the tentacles are expanded basally into gelatinous, paddle-shaped pedalia. Well-developed eye-spots or ocelli are present in addition to marginal sense organs or rhopalia, and the nervous system includes a marginal nerve ring of interconnected ganglia.

The life history has been described for only one species of sea wasp (Tripedalia cystophora), but it too is unique among cnidarians. Spermatophores produced by the male medusa are transferred to the female during a distinctive mating sequence (WERNER, 1973). The sessile polyp stage of Tripedalia is radially symmetrical except during metamorphosis, and a number of features characteristic of the typical scyphopolyp are lacking (WERNER et al., 1971). Finally, WERNER et al. (1971) observed that the entire polyp metamorphoses into a small medusa, in contrast to the process of 
strobilation in scyphozoans. Such differences led WERNER (1973) to conclude that Cubomedusae are unique in their development, systematics, and evolution, and he suggested that they merit recognition as a distinct class, the Cubozoa.

Our study was undertaken to elucidate the systematic position of the Cubomedusae based on the types of nematocysts occurring in the group. Taxa recognized on other grounds as natural assemblages within the phylum Cnidaria typically possess similar or identical nematocyst types (WEILL, 1934; WERNER, 1965).

\section{MATERIALS AND METHODS}

Nematocysts were examined in 10 specimens of Chiropsalmus quadrumanus collected in nearshore waters of Georgia and South Carolina, USA. The medusae, ranging in bell height from $2.0-6.5 \mathrm{~cm}$, were preserved in $5 \%$ buffered formaldehyde. Squashes prepared from the tentacles, manubrium, gastric flaments, and exumbrellar warts were examined for nematocysts using light microscopy. In each of the 10 medusae examined, length and width measurements were made on each nematocyst category found on each anatomical part. All measurements were made on undischarged capsules using an ocular micrometer. WEILL's (1934) classification was used in the identification of nematocyst categories.

\section{RESULTS AND DISCUSSION}

The nematocyst complement of Chiropsalmus quadrumanus consisted of three major categories, namely isorhizas, microbasic mastigophores, and heterotrichous microbasic euryteles. Measurements of the various types present are given in Table 1. Ellipsoidal isorhizas (Fig. 1a), similar in morphology to those of the deadly sea wasp Cbironex fleckeri (HALSTEAD, 1965), occurred in large numbers on the tentacles. These were morphologically unlike isorhizas described from scyphozoans of the orders Stauromedusae, Coronatae, Semaeostomeae, and Rhizostomeae by Weill (1934), Papenfuss (1936), and Calder (1971, 1972, 1974), particularly in the shape of the capsule, Ovoid isorhizas (Fig. 1b) with an indistinct, irregularly-coiled thread were found on the tentacles and exumbrellar warts.

Microbasic mastigophores (Fig. 1c) were present on the tentacles and exumbrellar warts. This nematocyst category is found in the Hydrozoa and Anthozoa but has not been observed in scyphozoans other than sea wasps. Within the Cubomedusac, mastigophores have been reported in spccies of the genera Carybdea, Chirodropus, Chironex, and Tamoya (HAlstead, 1965), in addition to Chiropsalmus.

Several size classes of heterotrichous microbasic euryteles were present in medusae of C. quadrumanus. Large euryteles (Fig. 1d) were observed among the mastigophores on the tentacles. These nematocysts are considered equivalent to the "tumiteles" reported in Carybdea rastoni and Carukia barnesi by SouTHcotT (1967). Euryteles of moderate size (Fig. 1e) were present in widely-spaced rows on the manubrium and tentacles. Small euryteles (Fig. 1f) occurred on the gastric filaments. Euryteles were 
similar in gross morphology to those described from various species of Scyphozoa (Weill, 1934; Papenfuss, 1936; Calder, 1971, 1972, 1974). The only noteworthy difference detected under light microscopy was a greater length to width ratio in the large euryteles of C. quadrumanus.

In addition to the nematocyst categories reported here from C. quadrumanus, Soutнсотт (1967) found anisorhizas in Carukia barnesi, the sea wasp responsible for
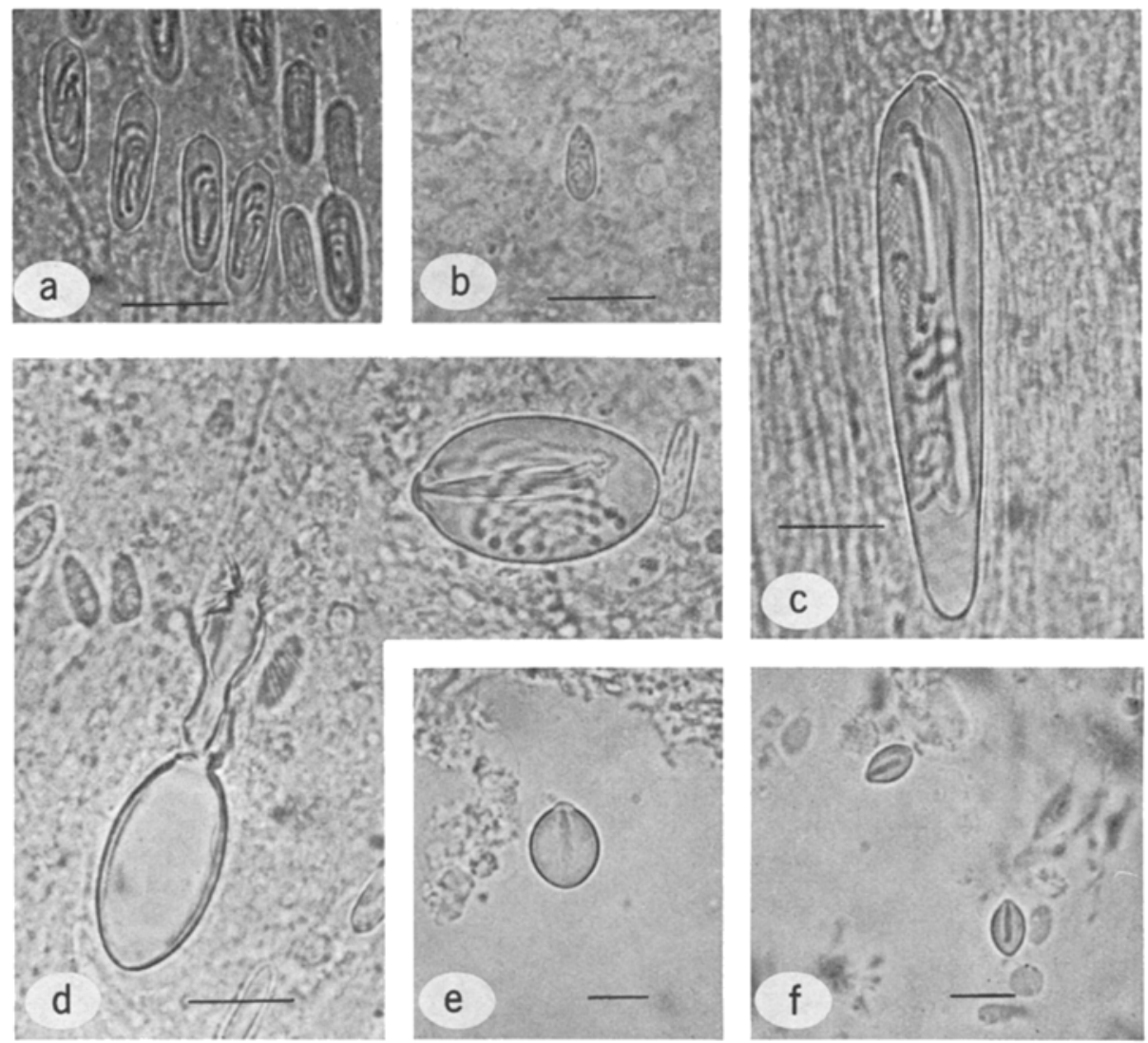

Fig. 1: Nematocysts from the medusa stage of Chiropsalmus quadrumanus. (a) Ellipsoidal isorhizas. (b) Ovoid isorhiza. (c) Microbasic mastigophore. (d) Large heterotrichous microbasic euryteles. (e) Medium heterotrichous microbasic eurytele. (f) Small heterotrichous microbasic euryteles. (Scale lines indicate $10 \%$ )

the "Irukandji Syndrome" of bathers in northern Australia. Anisorhizas of similar structure have been observed in a number of semaeostome and rhizostome medusae (Weill, 1934; Papenfuss, 1936; Calder, 1972).

Despite some similarities in the cnidome of Cubomedusae and scyphozoans of the orders Stauromedusae, Coronatae, Semaeostomeae and Rhizostomeae, the presence of microbasic mastigophores in sea wasps is considered a particularly significant differ- 
ence. This, together with differences in morphology and life history, supports the conclusion that the Cubomedusae are outside the mainstream of scyphozoan phylogeny and should be separated from the remaining orders of the class. While it is possible that a new class, the Cubozoa, should be recognized for the sea wasps (WERNER, 1973), a

T'able 1

Nematocysts of the sea wasp, Chiropsalmus quadrumanus

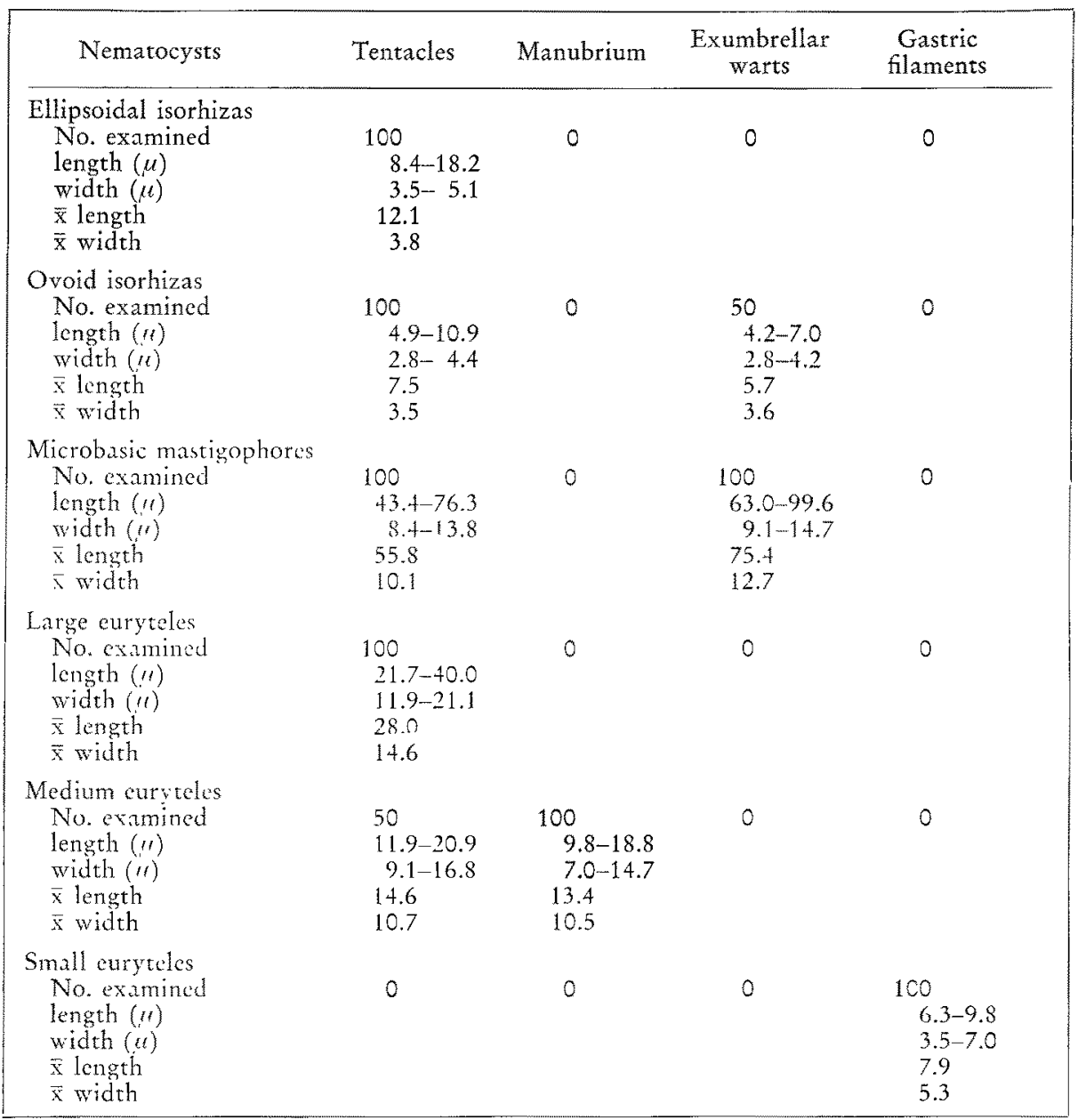

more conservative change in classification would involve recognizing two subclasses of Scyphozoa, one for the Cubomedusae and one for the remaining four orders of the class. The definition of the class Scyphozoa could then be broadened where necessary to encompass the sea wasps. Further studies on the systematic status of the group are warranted in any case. 


\section{SUMMARY}

1. Cubomedusae or "sea wasps" have generally been placed in the Scyphozoa, although they differ significantly in morphology from other representatives of the class. This study was undertaken to determine possible differences in the nematocyst complement of Cubomedusae and other scyphozoans.

2. Nematocysts were examined in specimens of the sea wasp Chiropsalmus quadrumanus from South Carolina and Georgia, USA. The cnidome of these medusae consisted of isorhizas, microbasic mastigophores, and heterotrichous microbasic euryteles.

3. Mastigophores occur in hydrozoans and anthozoans but have not been observed in scyphozoans other than sea wasps. Together with recent evidence from life history studies, this difference indicates that the Cubomedusae are sufficiently distinctive to merit recognition as either a separate subclass or class.

Acknowledgements. We thank M. H. Shealy, Jr. and J. N. KRaEuter for providing specimens of Chiropsalmus quadrumanus from South Carolina and Georgia respectively. Medusae collected in South Carolina were taken during studies supported by Coastal Plains Regional Commission Contract No. 10340031. This is Contribution No. 43 from the South Carolina Marine Resources Center.

\section{LITERATURE CITED}

Barnes, J. H., 1966. Studies on three venomous Cubomedusae. In: The Cnidaria and their evolution. Ed. by W. J. Rees. Acad. Press, New York, 307-332. Symp. zool. Soc. Lond. 16.

CALDER, D. R., 1971. Nematocysts of polyps of Aurelia, Cbrysaora, and Cyanea, and their utility in identification. Trans. Am, microsc. Soc. 90, 269-274.

- 1972. Nematocysts of the medusa stage of Rhopilema verrilli (Scyphozoa, Rhizostomeae). Trans. Am. microsc. Soc. 91, 213-216.

- 1974. Nematocysts of the coronate scyphomedusa, Linuche unguiculata, with a brief reexamination of scyphozoan nematocyst classification. Chesapeake Sci. 15, 170-173.

Cleland, J. B. \& SouthcotT, R. V., 1965. Injuries to man from marine invertebrates in the Australian region. Spec. Rep. Ser. natl. Hlth. med. Res. Coun., Canberra 12, 1-282.

Halstead, B. W., 1965. Poisonous and venomous marine animals of the world. U. S. Gov. Print. Off., Washington, D. C., 1, 297-371.

Kingston, C. W. \& Southcott, R. V., 1960. Skin histopathology in fatal jellyfish stinging. Trans. R. Soc. trop. Med. Hyg. 54, 373-384.

Papenfuss, E. J., 1936. The utility of the nematocysts in the classification of certain Scyphomedusae. Lunds Univ. Arsskr. (Avd. 2) 31 (11), 1-26.

Souтнсотт, R. V., 1967. Revision of some Carybdeidae (Scyphozoa: Cubomedusae), including a description of the jellyfish responsible for the "Irukandji Syndrome". Aust. J. Zool. 15, 651-671.

WeILL, R., 1934. Contribution à l'étude des cnidaires et de leurs nématocystes. I. Recherches sur les nématocystes (morphologie, physiologie, développement). II. Valeur taxonomique du cnidome. Trav. Stn. zool. Wimereux 10, 1-347; 11, 351-701.

Werner, B., 1965. Die Nesselkapseln der Cnidaria, mit besonderer Berüdssichtigung der Hydroida. I. Klassifikation und Bedeutung für die Systematik und Evolution. Helgoländer wiss. Meeresunters. 12, 1-39. 
- 1973. Spermatozeugmen und Paarungsverhalten bei Tripedalia cystophora (Cubomedusae). Mar. Biol. 18, 212-217.

- Cutress, C. E. \& Studebaker, J. P., 1971. Life cycle of Tripedalia cystophora Conant (Cubomedusae). Nature, Lond. 232, 582-583.

First author's address: D. R. CALDER

Marine Resources Research Institute

Charleston, South Carolina 29412

USA 